\title{
Comparison of Foley's catheter with PGE2 gel and Foley's catheter with PGE2 gel with extra amniotic saline infusion for labour induction
}

\author{
Shobha Bembalgi*, Lavanya, Vinutha M. B.
}

Department of Obstetrics and Gynecology, Karnataka Institute of Medical Sciences, Hubli, Karnataka, India

Received: 15 February 2018

Accepted: 09 March 2018

*Correspondence:

Dr. Shobha Bembalgi,

E-mail: subhasvb@gmail.com

Copyright: () the author(s), publisher and licensee Medip Academy. This is an open-access article distributed under the terms of the Creative Commons Attribution Non-Commercial License, which permits unrestricted non-commercial use, distribution, and reproduction in any medium, provided the original work is properly cited.

\section{ABSTRACT}

Background: Induction of labour is initiation of uterine contractions before the onset in order to vaginally deliver the foetoplacental unit. Common reasons for induction of labour are post-term and hypertensive disorders of pregnancy. The purpose of this study was to compare the efficacy of Foley catheter with intra cervical PGE2 gel and Foley catheter with PGE2 gel with extra amniotic saline infusion for induction of labour.

Methods: The clinical trial was conducted from November 2016 to April 2017 at Karnataka Institute of Medical Sciences, Hubballi. 80 pregnant women which included both primigravidae and multigravidae were alternatively divided into two groups. Group 1 received Foley's and PGE2 gel and group 2 received Foley's, PGE2 gel and extra amniotic saline infusion for induction of labour.

Results: Both groups were comparable with respect to maternal age, gestational age and indication for induction. There was no significant difference in the mean pre-induction Bishop score between two groups. In both the groups there was significant improvement in the Bishop score after 6 hours of induction. But progress in group 2 was greater than group $1(\mathrm{P}<0.05)$. The mean time from induction to delivery in group 2 was shorter and was statistically significant $(\mathrm{P}<0.05)$. There was no difference in mode of delivery, neonatal and maternal morbidity and mortality between 2 groups.

Conclusions: The present study showed that Foley's with PGE2 gel with extra amniotic saline infusion is better for labour induction though both groups appear to be effective agents.

Keywords: Extra-amniotic saline infusion, Foley Catheter, Labour induction, PGE2

\section{INTRODUCTION}

Induction of labour is initiation of uterine contractions before the onset in order to vaginally deliver the foetoplacental unit. ${ }^{1}$ Common reasons for induction of labour are post-term and hypertensive disorders of pregnancy. ${ }^{2,3}$ The state of cervix before induction is measured by Bishop Score and it is an important determinant of success or failure for induction. ${ }^{4}$ There are two means of cervical ripening prior to labour induction: mechanical-foley's catheter, laminaria tents and pharmacological-PGE1, PGE2 and PGF2 $\alpha$. Mechanical devices dilate the cervix by accessing the foetal membrane whereas pharmacological preparations cause connective tissue softening, cervical effacement and uterine activity. 5,6

Trans-cervical Foley's catheter causes mechanical dilatation of cervix and stimulates endogenous release of prostaglandins by separating the foetal membranes and releasing lysosomes from decidual cells. ${ }^{7,8}$ Intra-cervical application of PGE2 gel has both cervical ripening and contraction inducting effect. ${ }^{9}$ The addition of extraamniotic saline infusion alter the mechanics of cervical ripening by increasing prostaglandin release, thereby 
shortening the time of labour. Goal of the study was to compare foley's and PGE2 gel, with and without extraamniotic saline infusion for induction of labor in patients with an unfavorable cervix.

\section{METHODS}

The study was carried out in the Department of Obstetrics and Gynaecology, Karnataka Institute of Medical Sciences, HUBLI for a period of six months from November 2016 to April 2017 after approval from Institutional Ethics Committee.

A total of 80 participants were divided into two groups with 40 participants in each group. Group 1 received Foley's and PGE2 gel and group 2 received Foley's, PGE2 gel and extra amniotic saline infusion for induction of labour. All participants were in the age group of 18 to 35 years. Participants included both primigravida and multigravida with singleton pregnancy with cephalic presentation with Bishop's score $\leq 3$ with intact membranes and whose conditions fulfilled for Vaginal delivery.

Patients with multiple pregnancy, malpresentation, antepartum haemorrhage, previous uterine scar, medical diseases and absent membranes were excluded from the study.

Written and informed consent was taken for participation in the study. Participants underwent vaginal examination to determine Bishop score. Group 1 had a 14F Foley's catheter inserted through the cervix, outside the chorioamnion into the lower uterine segment, bulb was then inflated with $40 \mathrm{~mL}$ of sterile water and catheter taped with tension to the medial aspect of the patient's thigh. PGE2 gel containing $0.5 \mathrm{mg}$ of dinoprostone $(2.5$ $\mathrm{ml}$ ) in a pre-filled syringe was inserted intra-cervically 10.

Foley's was removed 12 hours after insertion, unless rupture of membranes occurred (at which time Foley's was removed) or the bulb expelled spontaneously. The remainder of the induction process proceeded according to the standard management of labour currently employed in Labour and Delivery.

Group 2 consisting of 40 parturients received Foley's inserted and prostaglandin application as outlined above. In addition, normal saline infusion was given through the catheter port of Foley's at $40 \mathrm{~mL} /$ hour by intravenous infusion pump, beginning immediately after insertion of the catheter and continuing until the catheter was removed or expelled 10 .

For the purpose of this study failed induction was defined as failure to enter into active phase of labour. Failure to progress was defined as progress slower than $1 \mathrm{~cm} / \mathrm{hr}$ during active phase of labour despite adequate uterine contractions for a minimum of 2 hours.
Active phase was defined as cervical dilatation of $4 \mathrm{~cm}$ with complete effacement. ${ }^{10}$ Successful induction was defined as occurrence of normal vaginal delivery within 24 hours of initiation of induction.

Single dose prophylactic antibiotic was administered to all patients. Amniotomy was done in active phase of labour for non-reassuring FHR and for secondary arrest of labour. Participants underwent vaginal examination at $6,12,18$ and 24 hours or when clinically indicated.

Change in bishop score after induction of labour, interval between induction of labour and active phase was noted. Total number of spontaneous rupture of membranes, mean duration from induction to spontaneous rupture of membranes, mean induction delivery interval was calculated. Mode of delivery, indication for Caesarean section, maternal and neonatal morbidity and mortality were noted.

Statistical analysis was performed using SPSS 2 version. Data was compared using independent t test. Statistical significance were defined as $\mathrm{P}<0.05$.

\section{RESULTS}

Out of 80 pregnant women who enrolled for the study, 40 were assigned to the Foley's and PGE2 gel group, remaining 40 were assigned to the foley's with PGE2 gel with Extra-amniotic saline infusion group.

Table 1 shows the age distribution of patients. All patients were in the age group between 18-40 years. In both the groups, maximum number of patients were $<25$ years.

Table 1: Age distribution of patients.

\begin{tabular}{|lll|}
\hline Age & Group 1 $(n=40)$ & Group $2(n=4: 0)$ \\
\hline$<25$ & 31 & 29 \\
\hline $25-35$ & 09 & 11 \\
\hline$>35$ & 00 & 00 \\
\hline
\end{tabular}

Table 2 shows gestational age of patients. All patients were between 34 weeks 0 days gestation to 43 weeks gestation. Maximum number of patients belonged to more than 40 weeks gestational age.

Table 2: Gestational age of patients.

\begin{tabular}{|llll|}
\hline Gestational age (weeks) & Group 1 & Group 2 & Total \\
\hline$<37$ & 03 & 04 & 07 \\
\hline $37-40$ & 21 & 14 & 35 \\
\hline 40 & 16 & 22 & 38 \\
\hline
\end{tabular}

Table 3 shows indication for pregnancy termination. In both the groups maximum induction of labour was for post term (16 and 19 in group 1 and 2 respectively). 
Table 3: Distribution of patients according to indication for induction of labour.

\begin{tabular}{lll} 
Indication & Group 1 & Group 2 \\
Post term & 16 & 19 \\
\hline Pre-eclampsia & 15 & 12 \\
Oligohydramnios & 2 & 3 \\
IUD & 4 & 2 \\
\hline Others & 3 & 4
\end{tabular}

Table 4 shows Bishops score of patient in both the groups before and after induction of labour. There was no significant difference in the mean pre-induction Bishop score between two groups. In both the groups there was a considerable improvement in the Bishop score after 6 hours of induction. But this progress in the group 2 was greater than group $1(\mathrm{P}<0.05)$.

Table 4: Bishop score.

\begin{tabular}{|llll|}
\hline Variables & Group 1 & Group 2 & P value \\
\hline $\begin{array}{l}\text { Mean pre-induction } \\
\text { Bishop score }\end{array}$ & $3.35+/-1.00$ & $3.13 \pm 0.69$ & 0.245 \\
$\begin{array}{l}\text { Mean post-induction } \\
\text { bishop score }\end{array}$ & $8.58+/-1.61$ & $9.80 \pm 1.67$ & 0.001 \\
\hline
\end{tabular}

Table 5 shows labour profile of patients. The mean time from induction of labour to active phase of labor in Group 2 was shorter (Group $17.82 \pm 1.38$ and Group 2 $6.45 \pm 1.47)$.

Table 5: Labour profile.

\begin{tabular}{|llll|}
\hline $\begin{array}{l}\text { Variables } \\
\text { Duration from }\end{array}$ & Group 1 & Group 2 & P value \\
induction to \\
$\begin{array}{l}\text { active phase } \\
\text { (hour) }\end{array}$ & $7.82 \pm 1.38$ & $6.45 \pm 1.47$ & 0 \\
\hline $\begin{array}{l}\text { Spontaneous } \\
\text { rupture of } \\
\text { membranes }\end{array}$ & 18 & 32 & - \\
$\begin{array}{l}\text { Interval from } \\
\text { induction to } \\
\text { rupture of } \\
\text { membranes(hou } \\
\text { r) }\end{array}$ & $8.36 \pm 2.59$ & $6.90 \pm 2.06$ & 0.007 \\
$\begin{array}{l}\text { Duration from } \\
\text { induction to } \\
\text { delivery }\end{array}$ & $19.25 \pm 3.85$ & $17.55 \pm 3.74$ & 0.049 \\
\hline
\end{tabular}

Number of patients having spontaneous rupture of membranes was higher in group 2 and the mean time from induction of labour to spontaneous rupture of membranes in group 2 was shorter. The mean time from induction to delivery in group 2 was shorter and was statistically significant $(\mathrm{P}<0.05)$.

Table 6 illustrates mode of delivery. Maximum numbers of patients in both the groups delivered vaginally.
However, group 2 had more vaginal deliveries than group 1.

Table 6: Mode of delivery.

\begin{tabular}{|lll|}
\hline Mode of delivery & Group 1 & Group 2 \\
\hline Vaginal & 23 & 29 \\
\hline Lscs & 17 & 11 \\
\hline
\end{tabular}

Table 7 shows the indication for Caesarean section. The most common reason for caesarean section in both the groups was failure to progress. There was no significant difference in caesarean section rate and indication for caesarean section between 2 groups.

Table 7: Indication for caesarean section.

\begin{tabular}{|lll|}
\hline Indication & Group 1 & Group 2 \\
\hline Failed induction & 2 & 2 \\
\hline Failure to progress & 6 & 4 \\
\hline Foetal distress & 5 & 3 \\
\hline Second stage arrest & 4 & 2 \\
\hline
\end{tabular}

Table 8 shows neonatal morbidity and mortality. There were no cases of chorioamnionitis in both the groups. Admission to NICU in group 1 was 6 and group 2 was 7 .

Table 8: Neonatal morbidity and mortality.

\begin{tabular}{|llll|}
\hline Variables & Group 1 & Group 2 & P value \\
\hline 1 min apgar score $<7$ & $7.25 \pm 1.48$ & $7.20 \pm 1.48$ & 0.881 \\
\hline 5 min apgar score $<7$ & $7.85 \pm 0.70$ & $7.90 \pm 0.63$ & 0.738 \\
\hline Nicu admission & 6 & 7 & \\
\hline Neonatal death & 1 & 0 & \\
\hline
\end{tabular}

There was 1 neonatal death in group 1. There was no significant difference in APGAR score at 1 and 5 minutes, admission to NICU and neonatal death. No case of maternal morbidity or mortality was noted in both the groups.

\section{DISCUSSION}

One of the common practices in modern obstetrical care is labour induction when foetal and maternal complications arise. ${ }^{11}$ Cervical ripening and induction of labour are debatable issues. ${ }^{12}$ An ideal ripening agent would be effective over a reasonably short time; it would cause minimal uterine activity during its period of effect; it would be reversible and not compromise other procedures that may follow; it would have no adverse effects on foetus or mother; it would be easy to administer; and which would be welcome in resource poor countries and inexpensive to use. ${ }^{13,14}$

In this study, efficacy of Foley with PGE2 gel was compared with Foley with PGE2 gel with extra-amniotic saline infusion for labour induction in the age group between 18 to 40 years. Both primigravida and 
multigravida were included in both the groups with each group consisting of 40 participants with same inclusion and exclusion criteria.

Results of this study showed that induction of labour with extra-amniotic saline infusion compared with other group had greater success regarding improvement in bishop score $(8.58 \pm 1.61$ in group 1 and $9.80 \pm 1.67$ in group 2), shorter mean time from Induction to delivery $(19.25 \pm 3.85$ in group 1 and $17.55 \pm 3.74$ in group 2) and shorter time from induction to active phase of labour $(7.82 \pm 1.38$ in group 1 and 6.451 .47 in group 2) in women with an unfavorable cervix and this was comparable to the study by Mandana Mansour Ghanaie et al. ${ }^{15}$

The overall cesarean delivery rate in this study were similar in both the groups (17 in group 1 and 11 in group 2) and distribution of indications leading to cesarean delivery (failure to progress) was similar in both the groups and was comparable to the study done by Niromanesh S et al. ${ }^{6}$

Neonatal outcome of the study did not show any difference in both the groups (6 and 7 admissions in group 1 and 2). This supports studies done by Atad $\mathbf{J}$ et al. ${ }^{16}$ No case of chorioamnionitis was detected in both the groups. One important concern was the possibility of causing ascending infection with Foley catheter and extra-amniotic saline infusion. However, we found no significant complication related to the use of this method.

Funding: No funding sources

Conflict of interest: None declared

Ethical approval: The study was approved by the Institutional Ethics Committee

\section{REFERENCES}

1. Joan Crane St, John's NF, Line L, Gregory J R. Induction of labour at term. J Obstet Gynaecol Can 2001;23(3):717-28.

2. Alec $\mathrm{S}$ McEwan. Induction of labour. Obstet Gynaecol Reprod Med. 2008;18(1):1-6.

3. Vellekoop J, Vrouenraets FP, van der Steeg JW, Mol BW, Roumen FJ. Indications and results of labour induction in nulliparous women: An interview among obstetricians, residents and clinical midwives. Eur J Obstet Gynecol Reprod Biol. 2009;146(2):1569.

4. Karjane NW, Brock EL, Walsh SW. Induction of labor using a foley balloon, with and without extraamniotic saline infusion. Obstet and Gynecol. 2006;107(2):234-9.

5. Ghanaei Mm, Sharami H, Asgari A. Labor induction in nulliparous women: a randomized controlled trial of foley catheter with extra-amniotic saline infusion. J Turkish German Gynecol Assoc. 2009;10:71-5.

6. Niromanesh S, Mosavi-Jarrahi A, Samkhaniani F. Intracervical Foley catheter balloon vs prostaglandin in preinduction cervical ripening. Int $\mathrm{J}$ Gynecol Obstet. 2003;81(1):23-7.

7. Sherman DJ, Frenkel E, Toblin J, Arieli S, Caspi E, Bukovasky I. Ripening of the unfavourable cervix with extra-amniotic catheter balloon: clinical experience and review. Obstet Gynecol Survey. 1996;51(10):621-7.

8. Arias F. Pharmacology of Oxytocin and Prostaglandins. Clin Obstet Gynecol. 2000;43(3):455-68.

9. Sorensen SS, Brocks V, Lenstrup C. Induction of labour and cervical ripening by intracervical prostaglandin E2. Obstet Gynecol. 1985;65(1):110-4.

10. Abramovici D, Goldwasser S, Mabie BC, Mercer BM, Goldwasser R, Sibai BM. A randomized comparison of oral misoprostol versus Foley catheter and oxytocin for induction of labor at term. Am J Obstet Gynecol. 1999;181(5):1108-12.

11. Rayburn WF. Preinduction cervical ripening: basis and methods of current practice. Obstet Gynecol Surv. 2002;57:683-92.

12. Zafarghandi A.Sh., Zafarghandi N, Baghaii N. Foley catheter cervical ripening with extraamniotic infusion of saline or corticosteroids: a double-blind, randomized controlled study. Acta Medica Iranica. 2004;42(5):338-42.

13. St. Onge RD, Connors GT. Preinduction cervical ripening: a comparison of intracervical prostaglandin E2 gel versus the Foley catheter. Am J Obstet Gynecol. 1995;172:687-90.

14. Sciscione AC, Nguyen L, Manley J, Pollock M, Maas B, Colmorgen G. A randomized comparison of transcervical Foley catheter to intravaginal misoprostol for pre-induction cervical ripening. Obstet Gynecol. 2001;97(4):603-7.

15. Ghanaie MM, Jafarabadi M, Milani F, Asgary SA, Karkan MF. A Randomized Controlled Trial of Foley Catheter, Extra-Amniotic Saline Infusion and Prostaglandin E2 Suppository for Labor. Induction J Family Reprod Health. 2013;7(2):49.

16. Atad J, Bornstien J, Calderon I, Petrikovsy BM, SorokinY, Aboronovici H. Non pharmaceutical ripening of the labor by a novel double balloon device. Obstet Gynecol. 1991;77(1):146-51.

Cite this article as: Bembalgi S, Lavanya, Vinutha MB. Comparison of Foley's catheter with PGE2 gel and Foley's catheter with PGE2 gel with extra amniotic saline infusion for labour induction. Int $\mathbf{J}$ Reprod Contracept Obstet Gynecol 2018;7:1782-5. 